\title{
Activity of Kincung Flowers (Etlingera Elatior (Jack) R.M.Sm.) on Total Leukocytes and Percentage of Leukocytes in Allergic Male White Mice
}

\author{
Yufri Aldi*, Elidahanum Husni, Relin Yesika
}

Yufri Aldi*, Elidahanum Husni, Relin Yesika

Faculty of Pharmacy, University Andalas, INDONESIA.

\section{Correspondence \\ Yufri Aldi}

Faculty of Pharmacy, University Andalas, INDONESIA

E-mail: yufrialdi@phar.unand.ac.id

History

- Submission Date: 08-10-2019;

- Review completed: 26-11-2019;

- Accepted Date: 06-12-2019.

\section{DOI : 10.5530/pj.2020.12.8}

Article Available online http://www.phcogj.com/v12/i1

Copyright

(C) 2020 Phcogj.Com. This is an openaccess article distributed under the terms of the Creative Commons Attribution 4.0 International license.

\begin{abstract}
Introduction: Kincung Flower (Etlingera elatior (Jack) R.M.Sm.) is a native herbal plant in Southeast Asia that traditionally used to many diseases, especially in Indonesia. Aim: This study was conducted to determine the activity of kincung (Etlingera elatior (Jack) R.M.Sm.) on the total number of leukocytes and differential leukocyte cells in allergic mice. Material and Methods: The semi-solid extract of Kincung flower (Etlingera elatior (Jack) R.M.Sm.) was made by the maceration method using $70 \%$ ethanol solvent. The animals used were 20 male white mice that have allergies of skin that treated with $20 \%$ albumen antigens given on the first day $0.2 \mathrm{~mL} / 20 \mathrm{~g}$ intraperitoneally, then on the seventh day are given antigens with the same dose subcutaneously. Allergic mice indicated by redness at the injection site. It divided into four groups: the negative control group and three dose groups (100; 300; and $1000 \mathrm{mg} / \mathrm{kg}$ ). On the seventh day after administration of the extract, observed the value of total leukocytes and differential leukocyte cells in mice. Results: The results after administration of extracts in 3 dose groups (100; 300; and $1000 \mathrm{mg} / \mathrm{kg}$ ) and the negative control group showed sequentially the total number of leukocytes was: $3.95 ; 4.73 ; 6.01$; and $3.6 \times 10^{3} / \mathrm{ML}$ and the percentage of leukocytes consisting of lymphocytes: $67.6 \% ; 62.0 \%$; $56.8 \%$ and $70.0 \%$, neutrophils: $22.4 \% ; 29.2 \% ; 36.8 \%$ and $20.0 \%$, eosinophils: $6.4 \% ; 5.8 \%, 4.2 \%$ and $6.6 \%$, monocytes: $3.6 \% ; 3.0 \%, 2.2 \%$ and $3.4 \%$, and basophils: $1.8 \% ; 1.4 ; 0.8 \%$ and $2.0 \%$. It concluded that kincung flowers could increase total leukocytes significantly $(p<0.05)$, decrease lymphocytes, eosinophils, basophils significantly $(p<0.05)$, increase neutrophils significantly $(p<0.05)$, and reduce monocytes insignificantly $(p>0.05)$. Conclusion: Kincung flowers (Etlingera Elatior (Jack) R.M.Sm.) can be used as an immunomodulator and decreasing the percentage of basophil cells, and eosinophils can used as an anti-allergic drug.
\end{abstract}

Key words: Allergies, Etlingera elatior (Jack) R.M.Sm, Kincung Flower, Leukocyte Percentage, Mice, Total Leukocytes.

\section{INTRODUCTION}

The immune system includes all structures and processes for the body's defence against disease. It cannot separate from the role of leukocytes which consist of several cells that have various types and functions that can respond to the presence of foreign objects that enter the body that can cause inflammation and infection. ${ }^{1}$ The immune system divided into two parts called the natural or innate (non-specific immune system) and the adaptive (specific immune system). The natural immune system will destroy all foreign objects that enter into the body even though it has never been exposed before while the adaptive immune system is specific to certain antigens that have previously been exposed that includes the process of recognizing specific antigens, then the formation of antibodies or $\mathrm{T}$ lymphocytes which will only react to specific antigens. ${ }^{2-4}$

Kincung Flower (Etlingera elatior (Jack) R.M.Sm.) is a herbal plant native to Southeast Asia which can found in several countries such as Indonesia, Malaysia, and southern Thailand. In Indonesia, it has been traditionally used to eliminate bad breath and body odour by brewing or boiling flower buds for drinking water.

Preliminary tests conducted stated that Etlingera elatior (Jack) R.M.Sm. has a phagocytic activity of macrophages against male white mice. It also has activity in inhibiting the active cutaneous anaphylactic reaction in mice, ${ }^{6}$ and also inhibit degranulation of mast cells in mice. ${ }^{7}$ The last study also stated that Etlingera elatior (Jack) R.M.Sm. has properties such as anti-cancer and tumors. ${ }^{8-10}$ and showed anticancer activity against cervical cancer cells, ${ }^{11}$ activity against skin cancer ${ }^{12}$ has high antioxidants ${ }^{13,14}$ and antibacterial to gram-positive bacteria Bacillus cereus, Micrococcus luteus, and Staphylococcus aureus, ${ }^{15,16}$ antidiabetic and antiinflammatory, ${ }^{17}$ whitening and antiaging. ${ }^{18}$

Etlingera elatior (Jack) R.M.Sm. contains many secondary metabolites such as alkaloids, flavonoids, saponins, tannins, terpenoid. ${ }^{19-21}$ Identification with GC-MS, Etlingera elatior (Jack) R.M.Sm. has compounds such as 1-dodecanol, dodecanal, 17-pentatriacontane, ${ }^{22}$ cyclododecane dan 1,1 dodecanediol diacetate. ${ }^{23}$ 
Based on the presence of kincung flower activity in inhibiting cutaneous-active hypersensitivity and macrophage phagocytosis, the researchers are interested in continuing research related to kincung activity on the number of leukocytes and the percentage of leukocytes in male mice hypersensitivity.

\section{MATERIAL AND METHOD}

\section{Place and time}

The research conducted in two months in April-September 2019. Preparation and extraction of Etlingera elatior (Jack) R.M.Sm. also determinating the characterisation from kincung flower's extract were conducted in three weeks at Central Laboratory in Faculty of Pharmacy Universitas Andalas.

\section{Tools and materials}

The equipment used in this study were the evaporator (Buchi ${ }^{\otimes} \mathrm{R}-210$ Rotavapor), UV-vis spectrophotometer (Thermo Scientific GENESYS 10S UV-Vis), beaker glass (Pyrex), erlenmeyer (Pyrex), Object glass microscope slides, pipette volume (Pyrex), digital analytical balance (Ohaus), Silica gel 60 F254 (Merck), desiccator, spatula, dark bottle, TLC vessel, mortar and mortar, sonde instrument, surgical instrument, filter paper, animal cage, haemocytometer, microscope.

The materials used in this study were kincung flower (Etlingera elatior (Jack) R.M.Sm.), aqua dest (Bratachem), ethanol 70\%, ethanol p.a (Merck), formic acid (Merck), Ethyl acetate (Merck), wright stain (B-Jes), Giemsa (B-Jes), Turk (B-Jes), EDTA, emersion oil, physiological $\mathrm{NaCl}$ (Widatra Bhakti), albumen, rutin comparison (Merck), methanol (Merck), ethanol 80\%, aluminium chloride (Merck), sodium acetate (Merck),

\section{Extracting Kincung Flower (Etlingera elatior (Jack) R.M.Sm)}

As much as $2 \mathrm{~kg}$ Etlingera elatior (Jack) R.M.Sm. was dried until it becomes dry simplicia, then proceed to make powder and sifted with sieve number 60 . As much as $250 \mathrm{~g}$ powder was macerated using $70 \%$ ethanol solvent (1:10), soaked for six first hour, stirring occasionally, then let stand for 18 hours. Twice repetition using the same type and amount of solvent. Filter using filter paper and the results of the mass are collected and then evaporated on a rotary evaporator until it becomes a thick extract (35.276 g).

\section{The TLC and total flavonoid test}

The some of parameters of standardisation of extract Etlingera elatior (Jack) R.M.Sm. were total flavonoid test and thin layer chromatography test (TLC) that based Indonesian Pharmacopea Herbal.

TLC test was from the routine that dissolved with ethanol $\mathrm{P}$, and the extract dissolved with methanol P. Put into the TLC plate (Silica gel 60 F25) into a chromatographic vessel which containing a mobile phase solution consisting of ethyl acetate $\mathrm{P}$, formic acid $\mathrm{P}$ and water (100: 15:17). Dry the TLC plate, then look under the UV light. ${ }^{24}$

Total flavonoid test was extract of Etlingera elatior (Jack) R.M.Sm. and routine solution dissolved in ethanol $80 \%$, then put extract solution in centrifuge. Then pipette $0.5 \mathrm{~mL}$ supernatant and routine solution, add $1.5 \mathrm{~mL}$ of ethanol, $0.1 \mathrm{~mL}$ of $\mathrm{AlCl}_{3} 10 \%, 0.1 \mathrm{~mL}$ of $\mathrm{Na}$ acetate 1 $\mathrm{M}$ and $2.8 \mathrm{~mL}$ aqua dest. Shake and put aside for 30 minutes at room temperature. Measure the absorption at the maximum absorption in wavelength $418 \mathrm{~nm} \cdot{ }^{24}$

\section{Calculate the percentage of leukocyte cells}

After seven days of preparation, the blood smear was made to count leukocytes by taking blood from mice from the vein, then drop the blood on the slide and use another slide to flatten, wait to dry. After dry fixation with methanol and wait for it to dry. Drops of diluted wright solution with Aquadest (1:20) to see basophil cells and 10\% Giemsa solution to see other leukocyte cells (neutrophils, monocytes, lymphocytes, eosinophils) then let stand for 20 minutes. Wash with aqua dest, observed under a microscope.

\section{Ethical test}

In this research using the mice, the subject of study, so it required an ethical test that qualifies to mitigate the treatment gave an adverse impact on a human subject in this research. The ethical test conducted by the Commission of Ethics Faculty of Medicine Universitas Andalas, Padang, Sumatera Barat.

\section{RESULTS AND DISCUSSION}

The extract of Etlingera elatior (Jack) R.M.Sm. was semi-solid extract with characterisation black-brown colour, characteristic odour, and sour taste. Its yield of $14.11 \%$, and according to Indonesian Pharmacopoeia Herbal, the yield percentage of kincung extract is not less than $9.86 \%$. Shrinkage of dried kincung flower extract is $6.65 \%$, and according to Indonesian Pharmacopoeia Herbal, it does not more than $10 \%$. The total ash content of kincung flower extract was $4.57 \%$, and according to Indonesian Herbal Pharmacopoeia it does not more than $7.5 \%$, while the ash content of kincung flower extract was insoluble in acid $0.02 \%$ and according to Indonesian Pharmacopoeia Herbal, it does not more than $0.1 \% .^{24}$

Determinating of total flavonoid used a routine as a standard that tested in UV-vis Spectro that obtain wavelength was $418 \mathrm{~nm}$. The linear regression of the routine comparison calibration curve for the calculation of total flavonoid levels was $\mathrm{y}=0.0046 \mathrm{x}-0.0562$ with $\mathrm{R} 2=$ 0.998 so that the total flavonoid concentration of kincung flower extract (Etlingera elatior (Jack) RMSm.) obtained was $1.564 \%$ and according to Indonesian Pharmacopoeia Herbal, the total flavonoid content of kincung extract (Etlingera elatior (Jack) M. Sm.) not less than $0.58 \%$ which is calculated as routine ${ }^{2.4}$ Total flavonoid extract rate calculated at $418 \mathrm{~nm}$ wavelength. The spectrum of UV showed in Figure 1.

According to Indonesian Pharmacopoeia Herbal, the TLC test of Etlingera elatior (Jack) RM.Sm. extract using ethyl acetate P: formic acid P: water (100:15:17) and silica gel 60 F254 and also using a rutin comparison. Results $\mathrm{Rf}$ value extract obtained as can be seen in Figure 2.

This study was conducted with the sensitisation of experimental animals with $20 \%$ albumen as much as $0.2 \mathrm{~mL} / 20 \mathrm{~g}$ bw intraperitoneally. Purebred albumen are used as antigens because these albumen immunogenic properties are quite high ${ }^{25}$, the protein content is around $12 .{ }^{26}$ The in vitro test in this study used sensitised mast cell. The purpose of this sensitisation is to generate a primary immune response where the

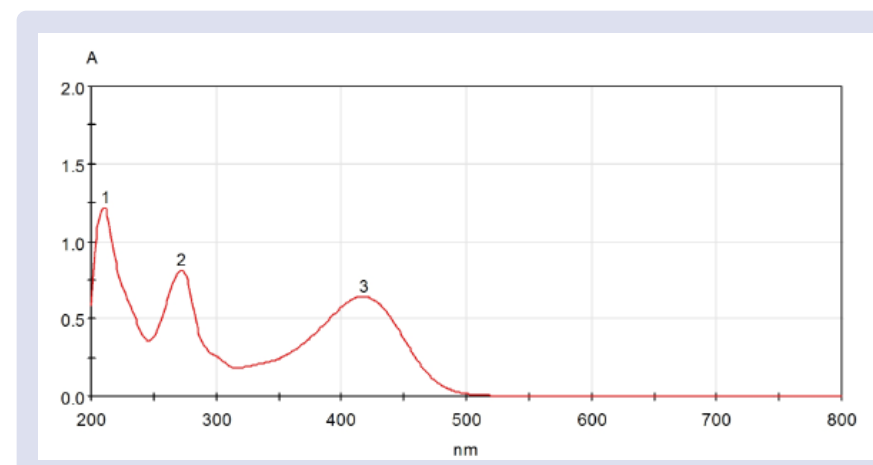

Figure 1: Ultraviolet-visible spectrum comparison of rutin-aluminum chloride. 


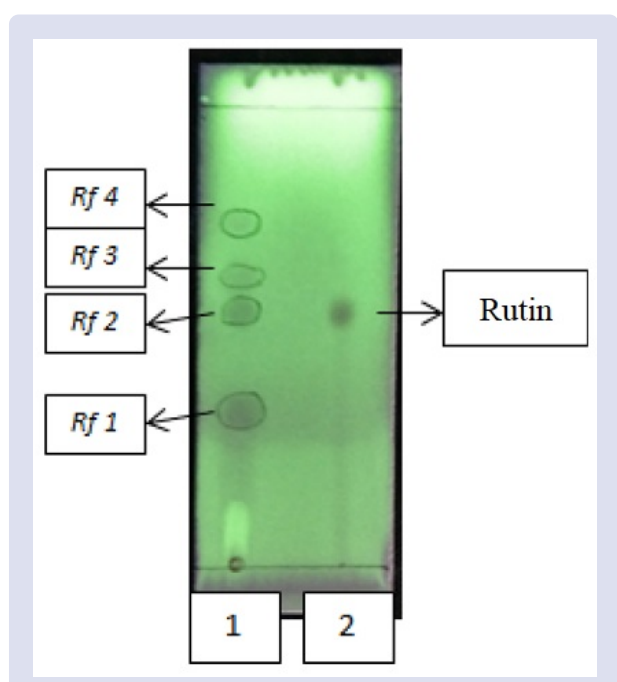

Figure 2: TLC kincung flower extract with eluent ethyl acetate P: formic acid P: water (100:15-17) and silica gel 60 F254. Description: 1 . TLC kincung flower extract 2 . routine comparison. There are four marks, and the routine showed in Rf2 with value of 0.446 . This extract has suitable for Indonesian Pharmacopoeia Herbal.

first antigen injection is performed intraperitoneally so that the process of antigen recognition is faster by lymphocyte cells. This recognition process is carried out by macrophages, where macrophages are one of the presenting cell antigens and widely found in the abdominal cavity. On the seventh day, a subcutaneous second injection of antigens was carried out to increase the formation of IgE antibodies, so that allergic reactions get worse. In a preliminary study of Etlingera elatior (Jack) R.M.Sm.) was tested in vitro to inhibit desensitised mast cell in white male mice. ${ }^{7}$ Desensitised mast cell-induced with albumen and allergic mice will be shown redness to red spots or bumps around the body and injection site. This reaction occurs when antigens bind to IgE antibodies that are on the surface of mast cells and basophils. This bond in a matter of minutes can cause mastocyte degranulation which results in the release of mediators, especially histamine. ${ }^{27}$ Allergy mice will then used for further treatment, except for the negative control group used normal mice. The formula for calculating the number of leukocytes per $\mu \mathrm{m}$ is: cells counted $\times 20(1: 20) \times 10(0.1 \mathrm{~mm}): 4$ (number of boxes in $\mu \mathrm{m}^{2}$ ) or number of cells counted in boxes multiplied by $5 .{ }^{28}$

Total leukocyte counts of male mice type 1 hypersensitivity mice showed in Table 1, and the relationship between total leukocyte counts by giving dosage variations showed in Figure 3. One-way Anova analysis of total leukocyte cells after ethanol extract of kincung flowers at doses of 100, 300 , and $1000 \mathrm{mg} / \mathrm{kg}$ in type I hypersensitivity mice showed a significant increase in the number of mouse leukocyte cells $(p<0.05)$. However, this increase is still in the normal range where normal mice cell leukocytes range from $2000-10000 \mathrm{cell} / \mu \mathrm{L} .^{29-31}$ The result of an increase in the total number of leukocyte cells showed in Table 2. An increase in the total number of leukocytes represents a humoral and cellular response against pathogenic agents or indicates an increase in the body's defence capability, ${ }^{32}$ where the function of leukocytes is to protect the body from pathogens by producing antibodies and phagocytic processes. Increased leukocytes are thought to contain flavonoids in kincung flowers. Flavonoids can enhance the immunomodulatory system by increasing the effectiveness of lymphokine proliferation produced by $\mathrm{T}$ cells so that it will stimulate phagocytic cells to respond to phagocytosis. ${ }^{33}$ Higher doses of flavonoids make leukocyte cells (phagocytes) more active against phagocytic bacterial cells, and more bacteria can be damaged and digested with leukocyte cells. ${ }^{34}$
The percentage of leukocytes, performed by Romanowsky staining method because this staining can give satisfactory results on peripheral blood smears. Giemsa and wright colouring is included in Romanowsky colouring .wright-stain to see basophil cells and neutrophil, lymphocytes, monocytes, eosinophils using Giemsa. Leukocyte count done by cross-sectioned or leukocyte count, which starts from the edge of the blood sample by snaking until 100 leukocyte cells are obtained then expressed in percentage..$^{35-37}$ The types of leukocytes that can be seen using Giemsa colouring showed in Figure 4. For the percentage of leukocytes, it showed in Table 2, and the relationship of percentage leukocytes with administering dose variations showed in Figure 5.

After one-way Anova analysis on the percentage of leukocytes after administration of kincung flower ethanol extract at doses of 100, 300 , and $1000 \mathrm{mg} / \mathrm{kg}$ bw in type I hypersensitivity mice (Figure 4) showed that there is a significant decrease in lymphocytes $(\mathrm{p}<0.05)$. The percentage of normal lymphocytes in mice is $70-80 \%$ of the total differential leukocytes. ${ }^{29,31,38}$ Decreased lymphocytes can be triggered by several things such as stress during the treatment process ${ }^{29,39}$, or with increasing age and when the number of neutrophils increases. ${ }^{38,39}$

The results of the One-way ANOVA analysis showed a significant increase in neutrophils $(\mathrm{p}<0.05)$. The standard percentage of neutrophils in mice is $20-30 \%$ of the total differential leukocytes. ${ }^{29,31}$ An increase in neutrophils or so-called neutrophilia is associated with responses to stress or excitement ${ }^{38}$ and usually increases in cases of bacterial infection and acute inflammation. . $^{4-42}$

The results of the one-way ANOVA analysis showed that monocytes were not significantly increased or decreased $(p>0.05)$. Monocytes are

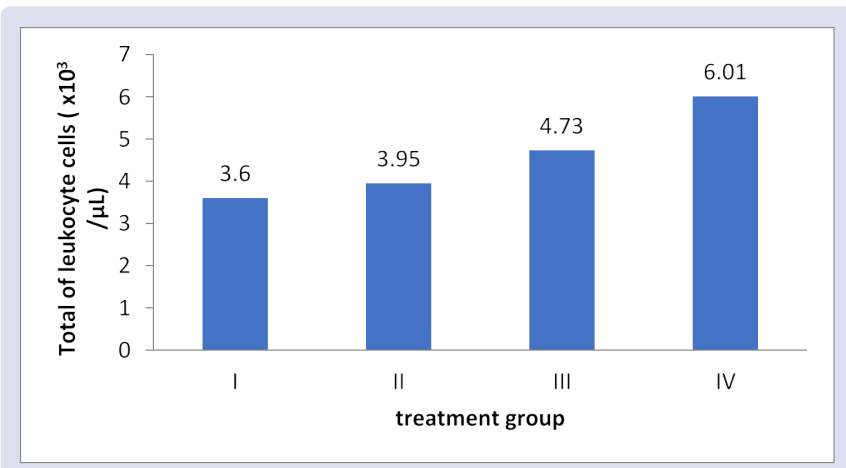

Figure 3: Relationship between dose variance with total leukocyte white male mice hypersensitivity.

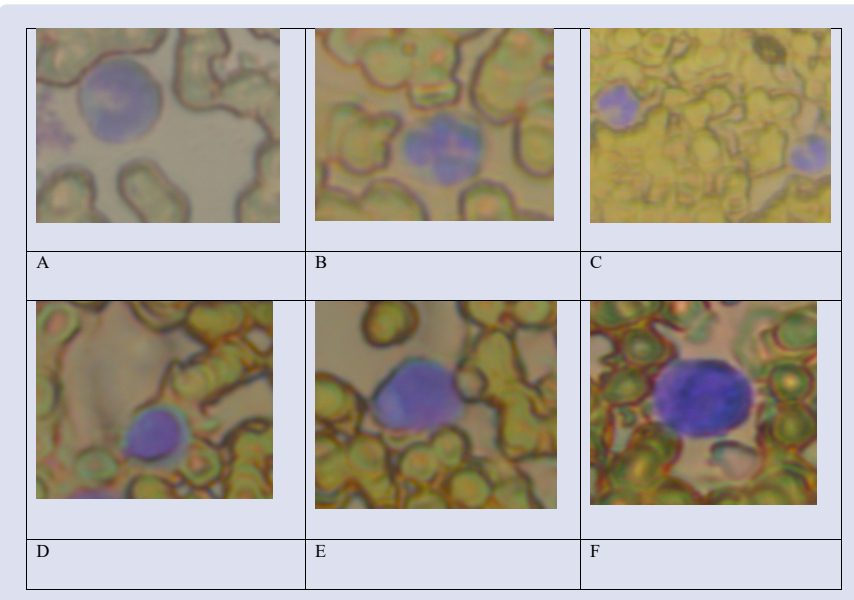

Figure 4: Differential of leukocyte cells. Descrption: A.stem neutrophils B.segment neutrophils C.eosinophils D.lymphocytes E.monocytes F. basophils. 
Table 1. Total of leukocyte cells in white male mice's blood after kincung flower (Etlingera elatior (Jack) R.M.Sm.) extract given for six days.

\begin{tabular}{lcccccc}
\hline \multirow{2}{*}{ Group } & \multicolumn{3}{c}{ Total of leukocytes $\left(\mathbf{x} 10^{3} / \mu \mathrm{L}\right)$} & \multicolumn{2}{c}{ Mean \pm SD } \\
\cline { 2 - 6 } & I & II & III & IV & V & 3.6 \\
I. Control group & 4.05 & 3.15 & 3.8 & 3.4 & $3.6 \pm 0.35$ \\
II. $100 \mathrm{mg} / \mathrm{kg}$ & 3.65 & 4.3 & 3.95 & 4.1 & 3.75 & $3.95 \pm 0.26$ \\
III. $300 \mathrm{mg} / \mathrm{kg}$ & 4.3 & 4.9 & 4.55 & 5.3 & 4.6 & $4.73 \pm 0.38$ \\
IV. $1000 \mathrm{mg} / \mathrm{kg}$ & 6.05 & 5.9 & 5.75 & 5.25 & 7.1 & $6.01 \pm 0.68$ \\
\hline
\end{tabular}

*Note: total leukocytes showed a significant increase $(p<0.05)$

Table 2. Percentage of leukocyte cells in white male mice's blood after kincung flower (Etlingera elatior (Jack) R.M.Sm.) extract given for six days.

\begin{tabular}{|c|c|c|c|c|c|}
\hline \multirow{2}{*}{ Group } & \multirow{2}{*}{ No } & \multicolumn{4}{|c|}{ Percentage of Leukocyte Cells (\%) } \\
\hline & & Lymphocytes & eosinophils & monocytes & neutrophils \\
\hline \multirow{5}{*}{ Control group } & 1 & 70 & 7 & 4 & 19 \\
\hline & 2 & 71 & 5 & 2 & 22 \\
\hline & 3 & 69 & 7 & 3 & 21 \\
\hline & 4 & 67 & 9 & 4 & 20 \\
\hline & 5 & 73 & 5 & 4 & 18 \\
\hline \multirow[t]{3}{*}{ Mean \pm SD } & & $70.0 \pm 2.23$ & $6.6 \pm 1.67$ & $3.4 \pm 0.89$ & $20.0 \pm 1.58$ \\
\hline & 1 & 71 & 6 & 4 & 19 \\
\hline & 2 & 65 & 8 & 5 & 22 \\
\hline \multirow[t]{3}{*}{ Doses $100 \mathrm{mg} / \mathrm{kg}$ bw } & 3 & 69 & 7 & 3 & 21 \\
\hline & 4 & 68 & 6 & 3 & 23 \\
\hline & 5 & 65 & 5 & 3 & 27 \\
\hline \multirow[t]{3}{*}{ Mean $\pm \mathrm{SD}$} & & $67.6 \pm 2.60$ & $6.4 \pm 1.14$ & $3.6 \pm 1.07$ & $22.4 \pm 3.39$ \\
\hline & 1 & 63 & 5 & 2 & 30 \\
\hline & 2 & 64 & 6 & 3 & 27 \\
\hline \multirow[t]{3}{*}{ Doses $300 \mathrm{mg} / \mathrm{kg}$ bw } & 3 & 62 & 5 & 4 & 29 \\
\hline & 4 & 60 & 6 & 3 & 31 \\
\hline & 5 & 61 & 7 & 3 & 29 \\
\hline \multirow[t]{3}{*}{ Mean \pm SD } & & $62.0 \pm 1.58$ & $5.8 \pm 0.83$ & $3.0 \pm 1.03$ & $29.2 \pm 1.48$ \\
\hline & 1 & 51 & 4 & 3 & 42 \\
\hline & 2 & 58 & 3 & 2 & 37 \\
\hline \multirow[t]{3}{*}{ Doses $1000 \mathrm{mg} / \mathrm{kg}$ bw } & 3 & 68 & 4 & 2 & 26 \\
\hline & 4 & 51 & 4 & 3 & 42 \\
\hline & 5 & 56 & 6 & 1 & 37 \\
\hline Mean \pm SD & & $56.8 \pm 6.97$ & $4.2 \pm 1.09$ & $2.2 \pm 1.07$ & $36.8 \pm 6.53$ \\
\hline
\end{tabular}


Table 3. Percentage of basophils in white male mice's blood after kincung flower (Etlingera elatior (Jack) R.M.Sm.) extract given for six days.

\begin{tabular}{|c|c|c|c|c|c|c|}
\hline \multirow{2}{*}{ Group treatment } & \multicolumn{5}{|c|}{ Mice } & \multirow{2}{*}{$\%$ Mean \pm SD } \\
\hline & 1 & II & III & IV & V & \\
\hline I .Control group & 2 & 1 & 2 & 3 & 2 & $2.0 \pm 0.70$ \\
\hline II. $100 \mathrm{mg} / \mathrm{kg}$ bw & 1 & 3 & 2 & 1 & 2 & $1.8 \pm 0.83$ \\
\hline III. $300 \mathrm{mg} / \mathrm{kg}$ bw & 1 & 2 & 2 & 1 & 1 & $1.4 \pm 0.57$ \\
\hline IV. $1000 \mathrm{mg} / \mathrm{kg}$ bw & 1 & 0 & 1 & 1 & 1 & $0.8 \pm 0.44$ \\
\hline
\end{tabular}

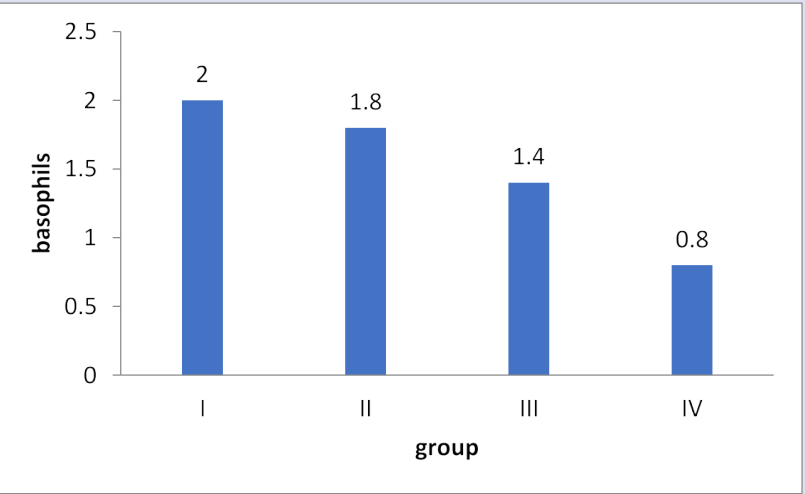

Figure 6: Relationship between dose variance with percentage of basophils in white male hypersensitivity mice.

the largest leukocytes, and the standard percentage of monocytes in mice ranges between $2-6 \%$ of the circulating cell population and their numbers increase in response to infection. ${ }^{43}$ Decrease in the number of monocytes at doses of 300 and $1000 \mathrm{mg} / \mathrm{kg}$ is estimated because monocytes migrate to tissue or to the location of damage or infection where they then mature into macrophages. Monocytes, along with macrophages and tissue neutrophils are the primary cells involved in first-line defence against pathogenic organisms or foreign cells. ${ }^{44}$

Percentage of basophils in male white hypersensitivity mice showed in Table 3, and the relationship of the percentage of leukocytes administering dose variations showed in Figure 6.

The results of the one-way ANOVA analysis showed a significant decrease in eosinophils and basophils $(\mathrm{p}<0.05)$. The number of basophil cells in the blood is deficient, the percentage of healthy basophil cells $<2 \%{ }^{45}$ and eosinophil $0-7 \%$ of the total differential leukocytes. ${ }^{29,31}$ Decreasing basophils and eosinophils can used as an indicator of antihypersensitivity. Basophils or eosinophils will increase during the response to antigens, parasites, and allergies. ${ }^{46,47}$ Basophils are one of the granulocytes involved in the thought process where the antigen enters a second time, and then the antigen is immediately bound by the IgE pair that is on the surface of the basophil cell. ${ }^{45,47}$ Cells will change the degranulation process and release mediators such as histamine, serotonin, prostaglandins, et cetera. The mediator is responsible for the onset of reactions such as itching, redness, oedema, and tissue dysfunction. ${ }^{47,48}$

In previous studies, it stated that flavonoids could inhibit IL-4 and IL-13 by activation of basophil cells. ${ }^{49}$ Routine also stated have an antiallergic activity that affect to mast cell activity mediated by $\operatorname{IgE} .^{50,51}$

\section{CONCLUSION}

The results of this study concluded that kincung flowers could increase the number of leukocytes significantly $(\mathrm{p}<0.05)$, decrease lymphocytes, eosinophils, basophils significantly $(\mathrm{p}<0.05)$, increase neutrophils significantly $(p<0.05)$ and does not increase monocytes significantly $(p>0.05)$. Increased total leukocytes after gave kincung flower extract can be used as an immunomodulator, and a decrease in the percentage of basophil cells and eosinophils can used as an allergic drug.

\section{ACKNOWLEDGEMENTS}

The authors would like to deliver a special appreciation to the Dean of Faculty of Pharmacy of Universitas Andalas for the financial support based on Research Grant of faculty of Pharmacy Universitas Andalas.

\section{CONFLICTS OF INTEREST}

The author(s) declare(s) that there is no conflict of interest regarding the publication of this article.

\section{REFERENCES}

1. Katzung, BG. Basic Pharmacology and Clinic First Edition. Jakarta: Salemba Medika; 2001.

2. Baratawidjaja K, I Rengganis. Basic Immunology, $11^{\text {th }}$. Balai Penerbit Fakultas Kedokteran UI. Jakarta; 2014.

3. Sinha JK, S Bhattacharya. A Textbook of Immunology. Academic Publishers, 2006.

4. Cruse, Julius M, Robert E Lewis. Atlas of immunology. CRC Press, 2010.

5. Hidayat, Ir R. Syamsul, M. Si, Rodame M. Napitupulu. The Handbook of Drug Plants. AgriFlo, 2015

6. Kardela, Widya, Yufri Aldi, and Rozi Efendi. The Effect of Anti Anaphylaxis of Active Kutan From Ethanol Extract of Kincung Flower (Etlingera elatior (Jack) RM Smith) on White Male Mice. Journal Farmasi Higea. 2017;9(1):30-40

7. Aldi Y, R Yesika, dan Z, Rizal. Ethanol Test of Kincung Flower (Etlingera elatio (Jack) RM Sm) in Inhibiting the Degranulation of Male White Mice Mastocytes Active In vitro. Prosiding Nasional \& Workshop Perkembangan Terkini Sains Farmasi \& Klinik 6, Fakultas Farmasi Unand. 2016;1-10.

8. Murakami, Akira, Abdul Manaf Ali, Kamaruddin Mat-Salleh, Koichi Koshimizu, Hajime Ohigashi. Screening for the in vitro anti-tumour-promoting activities of edible plants from Malaysia. Bioscience, Biotechnology, and Biochemistry. 2000;64(1):9-16.

9. Lestari Tresna. Potential of Anticancer from kecombrang flower extract with various policy levels on $T_{47} D$ cells. Jurnal Kesehatan Bakti Tunas Husada: Jurnal IImu-ilmu Keperawatan, Analis Kesehatan dan Farmasi. 2015;14(1):8-11.

10. Ghasemzadeh, Ali, Hawa ZE Jaafar, Asmah Rahmat, Sadegh Ashkani. Secondary metabolites constituents and antioxidant, anticancer and antibacterial activities of Etlingera elatior (Jack) RM Sm grown in different locations of Malaysia. BMC Complementary and Alternative Medicine. 2015;15(1):335.

11. Habsah M, Anita Mohd Ali, NH Lajis, M. SukariYH Yap, H Kikuzaki, N Nakatani. Antitumour-promoting and cytotoxic constituents of Etlingera elatior. The Malaysian Journal of Medical Sciences: MJMS. 2005;12(1):6. 
12. Krajarng, Aungkana, Malin Chulasiri, Ramida Watanapokasin. Etlingera elatior Extract promotes cell death in B16 melanoma cells via down-regulation of ERK and Akt signaling pathways. BMC Complementary and Alternative Medicine. 2017; 17(1):415

13. Wijekoon, MM Jeevani Osadee, Rajeev Bhat, Alias A. Karim. Effect of extraction solvents on the phenolic compounds and antioxidant activities of bunga kantan (Etlingera elatior Jack.) inflorescence. Journal of Food Composition and Analysis. 2011;24(4-5):615-9.

14. Andarwulan, Nuri, Ratna Batari, Diny Agustini Sandrasari, Bradley Bolling, Hanny Wijaya. Flavonoid content and antioxidant activity of vegetables from Indonesia. Food Chemistry. 2010;121(4):1231-5.

15. Chan, Eric Wei Chiang, Yau Yan Lim, Mohammed Omar. Antioxidant and antibacterial activity of leaves of Etlingera species (Zingiberaceae) in Peninsular Malaysia. Food Chemistry. 2007;104(4):1586-93.

16. Lachumy, Subramanion Jo Thy, Sreenivasan Sasidharan, Vello Sumathy, and Zakaria Zuraini. Pharmacological activity, phytochemical analysis and toxicity of methanol extract of Etlingera elatior (torch ginger) flowers. Asian Pacific Journal of Tropical Medicine. 2010;3(10):769-74.

17. Srey, C., C. Sontimuang, S. Thengyai, C. Ovatlarnporn, and P. Puttarak. Ant $\alpha$-glucosidase, anti $\alpha$-amylase, anti-oxidation, and anti-inflammation activities of Etlingera elatior rhizome. Journal of Chemical and Pharmaceutical Research. 2014;6(12):885-91.

18. Nithitanakool, Saruth, Veerawat Teeranachaideekul, Lakkhana Ponpanich, Nisa Nopporn, Tipwimol Junhunkit, Pimphaka Wanasawas, and Malyn Chulasiri. In vitro and in vivo skin whitening and anti-aging potentials of hydroglycolic extract from inflorescence of Etlingera elatior. J Asian Assoc Sch Pharm. 2014;3:31425.

19. Khor, Poh-Yen, Fatin Shuhada Na'im Mohamed, Ikrimah Ramli, Nur Fatihah Asyiqin Mohd Nor, Siti Khatijah Che Mohd Razali, et al. Phytochemical, antioxidant and photo-protective activity study of bunga kantan (Etlingera elatior) essential oil. Journal of Applied Pharmaceutical Science. 2017;7(08):209-13.

20. Lachumy, Subramanion Jo Thy, Sreenivasan Sasidharan, Vello Sumathy, and Zakaria Zuraini. Pharmacological activity, phytochemical analysis and toxicity of methanol extract of Etlingera elatior (torch ginger) flowers. Asian Pacific Journal of Tropical Medicine. 2010;3(10):769-74.

21. Wijekoon, MM Jeevani Osadee, Rajeev Bhat, and Alias A. Karim. Effect of extraction solvents on the phenolic compounds and antioxidant activities of bunga kantan (Etlingera elatior Jack.) inflorescence. Journal of Food Composition and Analysis. 2011;24(4-5):615-9.

22. Maimulyanti, Askal, and Anton Restu Prihadi. Chemical composition, phytochemicals and antioxidant activity from extract of Etlingera elatior flower from Indonesia. Journal of Pharmacognosy and Phytochemistry. 2015;3(6):233-8.

23. Jaafar, Faridahanim Mohd, Che Puteh Osman, Nor Hadiani Ismail, and Khalijah Awang. Analysis of essential oils of leaves, stems, flowers and rhizomes of Etlingera elatior (Jack) RM Smith. The Malaysian Journal of Analytical Sciences. 2007;11(1):269-73

24. Republic of Indonesia Ministry of health. Indonesian herbal pharmacopoeia. Second edition. Republic of Indonesia ministry of health. Jakarta. 2001.

25. Kim, Sang-Hyun, Taeg Kyu Kwon, and Tae-Yong Shin. "Antiallergic effects of Vitis amurensis on mast cell-mediated allergy model." Experimental biology and medicine 233, no. 2 (2008): 192-199.

26. Sirait, c. H. " eggs and their processing." pusat penelitian dan pengembangan peternakan, bogor (1986)

27. Kimura, Masayasu, Isami Waki, and Masaya kokubo. "inhibition of compound 48/80-mediated histamine release from isolated rat mast cells by oosponolrelated compounds (4-acyl-isocoumarins)." the Japanese journal of pharmacology 28.5 (1978): 693-697.

28. Moyes, christopher d., and patricia m. Schulte. Principles physiology of animal. Vol. 754. San francisco: pearson benjamin cummings, 2008

29. O'connell, karyn e., et al. "Practical murine hematopathology: a comparative review and implications for research."Comparative medicine 65.2 (2015): 96113.
30. Moore, d. M. "haematology of the mouse (mus musculus)." schalm's veterinary hematology (2000): 1219-1224.

31. Provencher bolliger, a., et al. "Hematology of laboratory animals." schalm's veterinary hematology, 6th edition. Blackwell publishing Itd, lowa (2010): 852887.

32. Moyes, christopher d., and patricia m. Schulte. Principles of animal physiology. Vol. 754. San francisco: pearson/benjamin cummings, 2008.

33. Santoso, Tresna asih, Diniatik diniatik, and anjar mahardian kusuma. "Effect of immunostimulator of katuk leaves (sauropus androgynus I merr) ethanol extract against phagocytic activities of macrophages." pharmacy: jurnal farmasi indonesia 10.01 (2013).

34. Zalizar, lili. "flavonoids of phylanthus niruri as immunomodulators a prospect to animal disease control." arpn journal of science and technology 3.5 (2013): 529-532.

35. Bain, barbara j. Blood cells: a practical guide. John wiley \& sons, 2014.

36. Akrom, akrom, and ermawati mi. "description of amount and calculation of leukosites and blood general time in the betina rat induced by 7, 12-dimetilbenz $(\alpha)$ antrasen (dmba) after the granting of black jinten ethanol extract (nigella sativa I) the number of total leucocytes and coagulation time" jurnal tumbuhan obat indonesia 2.2 (2009): 69-78.

37. Svobodova, Zdenka, and B. Vykusova. Diagnostics, prevention and therapy of fish diseases and intoxications. Manual. Research Inst. of Fish Culture and Hydrobiology, 1991.

38. Treuting, Piper M., et al., eds. Comparative anatomy and histology: a mouse and human atlas (expert consult). Academic Press, 2011.

39. Schwab, Carlton L., et al. "Modeling and predicting stress-induced immunosuppression in mice using blood parameters." Toxicological Sciences 83.1 (2004): 101-113.

40. Jain NC. Comparative hematologic features of some avian and mammalian species, p 54-71 In: Jain NC, editor. Essentials of veterinary hematology. (1993). Philadelphia (PA): Lea and Febiger.

41. Brown, D. E., et al. "Salmonella enterica causes more severe inflammatory disease in C57/BL6 Nramp1G169 mice than Sv129S6 mice." Veterinary pathology 50.5 (2013): 867-876.

42. Brown, Diane E., et al. "Chronic murine typhoid fever is a natural model of secondary hemophagocytic lymphohistiocytosis." PLoS One 5.2 (2010): e9441.

43. Suckow, Mark A., Karla A. Stevens, and Ronald P. Wilson, eds. The laboratory rabbit, guinea pig, hamster, and other rodents. Academic Press, 2012.

44. Ward, Jerrold M., Sindhu Cherian, and Michael A. Linden. "Hematopoietic and Lymphoid Tissues." Comparative Anatomy and Histology. Academic Press, 2018. 365-401.

45. Dvorak, Ann M. Ultrastructure of mast cells and basophils. Vol. 85. Karger Medical and Scientific Publishers, 2005.

46. Furuya, Yuriko, et al. "Stimulation of bone formation in cortical bone of mice treated with a receptor activator of nuclear factor- $\kappa$ B ligand (RANKL)-binding peptide that possesses osteoclastogenesis inhibitory activity." Journal of Biological Chemistry 288.8 (2013): 5562-5571.

47. Stone, Kelly D., Calman Prussin, and Dean D. Metcalfe. "IgE, mast cells, basophils, and eosinophils." Journal of Allergy and Clinical Immunology 125.2 (2010): S73-S80.

48. Parslow, T.G., Daniel S.P., Abba T.I., \& John I.B. Medical Immunology (10th ed) Large medical books/Mc Graw hill medical publishing division, 199-203. 2001.

49. Gullón, Beatriz, et al. "Rutin: A review on extraction, identification and purification methods, biological activities and approaches to enhance its bioavailability." Trends in Food Science \& Technology 67 (2017):220-35.

50. Kim, Hee-Yun, et al. "Protective effects of rutin through regulation of vascular endothelial growth factor in allergic rhinitis." American Journal of Rhinology \& Allergy. 2015;29(3):e87-e94. 


\section{GRAPHICAL ABSTRACT}

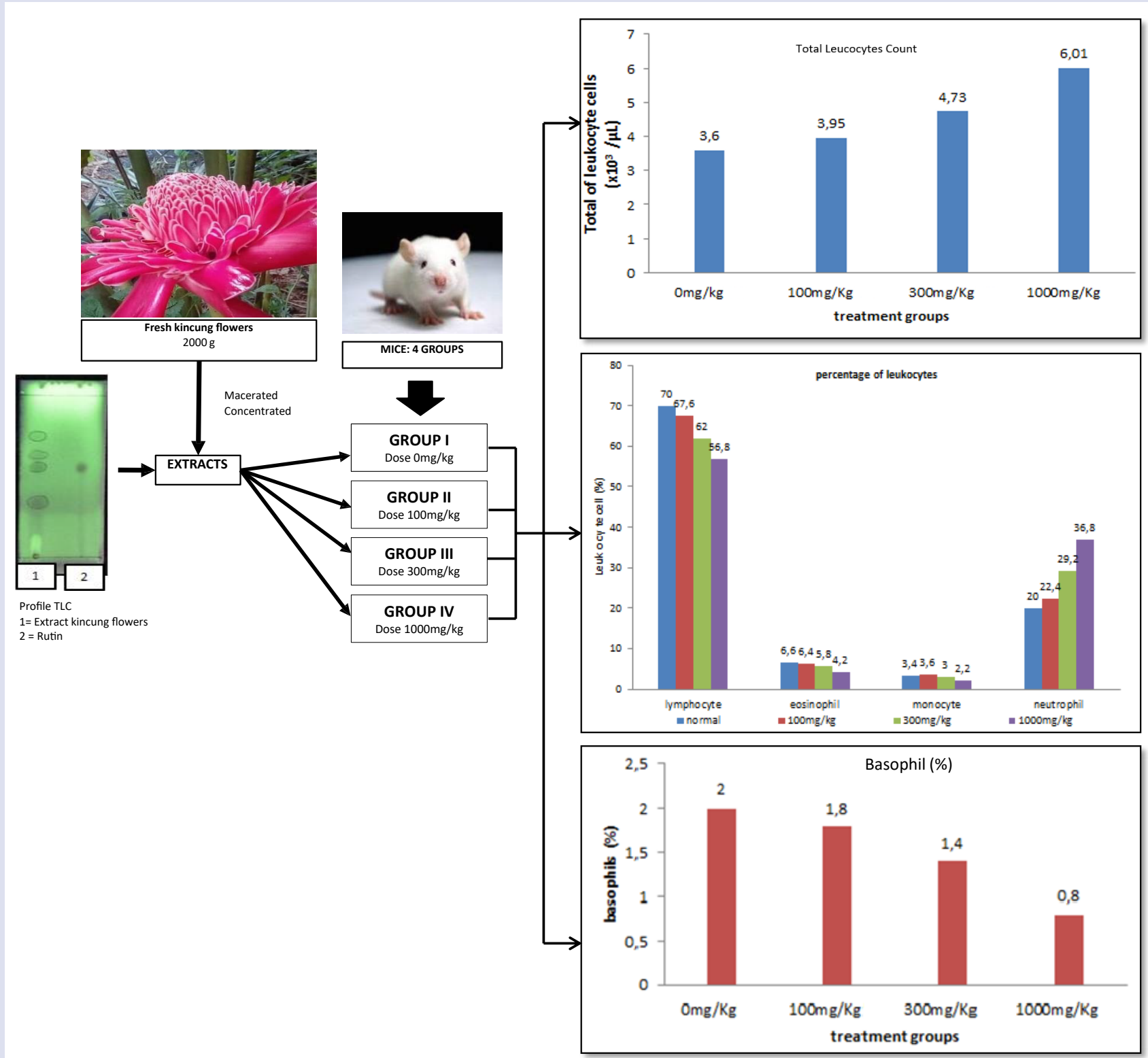

\section{SUMMARY}

Research on the activity of kincung flower extract (Etlingera elatior (Jack) R.M.Sm.) on the total number of leukocytes and the percentage of leukocytes was carried out. Kincung flower (Etlingera elatior (Jack) R.M.Sm.) tested in the form of thick extract that had standardised according to Indonesian herbal pharmacopoeia. Kincung flower extract (Etlingera elatior (Jack) R.M.Sm.) was given to male white mice for seven days at doses of 100,300, $1000 \mathrm{mg} / \mathrm{kg}$ body weight. Kincung flower extract (Etlingera elatior (Jack) R.M.Sm.) can increase the total number of leukocytes and neutrophils significantly, decrease lymphocytes, eosinophils, and basophils significantly, and decrease monocytes insignificantly.

\section{ABOUT AUTHORS}

- Dr. Yufri Aldi, M.S.i., Apt.: Currently as a lecturer at the Faculty of Pharmacy, University Andalas. Graduated from Faculty of Pharmacy Universitas Andalas in 1989, then Master Program in 1994 at School of Pharmacy Institut Teknologi Bandung (ITB Bandung) and Doctoral Program in Department Biomedical, Faculty of Medicine, University Andalas in 2013. The research and expertise are in Pharmaco-Immunology. Currently working as an assistant to the First Vice-Rector of Universitas Andalas and Head of the Department Doctoral Programme Pharmacy of Faculty of Pharmacy, Universitas Andalas. 
- Dr. Elidahanum Husni, M.Si, Apt.: Currently as a lecturer at the Faculty of Pharmacy, University Andalas. Graduated from Faculty of Pharmacy Universitas Andalas in 1986, then Master Program in 1995 at School of Pharmacy Institut Teknologi Bandung (ITB Bandung) and Doctoral Program in Department Biomedical, Faculty of Medicine, University Andalas in 2015. The research and expertise Pharmacognosy.

- Relin Yesika, Apt: She is a Graduate student in Faculty of Pharmacy Andalas University who was involved in assisting this research.

Cite this article: Aldi Y, Husni E, Yesika R. Activity of Kincung Flowers (Etlingera Elatior (Jack) R.M.Sm.) on Total Leukocytes and Percentage of Leukocytes in Allergic Male White Mice. Pharmacog J. 2020;12(1):44-51. 